\title{
COMPARATIVE RESEARCH OF ETIQUETTE NOUNS IN ENGLISH, UKRAINIAN AND HUNGARIAN
}

\author{
Fabian M. P.
}

\section{INTRODUCTION}

Comparative linguistics is the study of similarities and differences between languages, in particular the comparison of related languages with a view to reconstructing forms in their lost parent languages. It is the study of the relationships or correspondences between two or more languages and the techniques used to discover whether the languages have a common ancestor. Contrastive linguistics can be regarded as a branch of comparative linguistics that is concerned with pairs of languages which are "socio - culturally linked". Two languages can be said to be socio - culturally linked when a) they are used by a considerable number of bi- or multilingual speakers, and/or b) a substantial amount of "linguistic output" (text, oral discourse) is translated from one language into another. Comparative linguistics is also treated as a science dealing with the study of similarities between languages: analyzing genetic relationships (phonetics) and typological relationships (syntax and morphology), whereas Contrastive linguistics - as the one focusing on differences between languages (foreign language pedagogy). Comparative linguistics (originally comparative philology) is a branch of historical linguistics that is concerned with comparing languages in order to establish their historical relatedness. The latter implies a common origin or proto - language, and comparative linguistics aims to reconstruct proto - languages and specify the changes that have resulted in the documented languages. The term comparative language or comparative linguistics refers to the analysis of different language systems in order to determine their histories, evolutions and interconnections. Despite minor differences in all the abovementioned definitions of the subject matter of comparative linguistics, they all contain the main essence of it, i.e. it is a subdiscipline of linguistics which is concerned with the comparison of two or more languages (or subsystems of languages) in order to determine both the differences and similarities that hold between them. The object of comparative linguistics is two or more languages regardless of their genealogical and typological nature.

The comparative study of language systems is a vast field which needs further investigation and is open to discussion, especially concerning its methods and procedures of linguistic research. It is one of the most promising and topical trends of contemporary linguistics. Furthermore, of great importance is the comparative analysis of both related and unrelated languages. 
The latter very rarely become the topic of comparative language studies, though, in our opinion, they are worthy of attention and further study. The questions whether different languages resemble each other to any extent, or whether they are totally different have always fascinated, and continue to fascinate linguists of various linguistic schools: some prefer to focus on foreign language teaching peculiarities when dealing with comparative language studies, others - on cross-language and cross-cultural communication issues.

Contemporary linguistics is characterized by intensification of interest concerning typological studies of languages possessing different structures, their comparison with other related, distantly related and unrelated language systems. For typological comparison, time factor is of no essential value, and it is determined as an overtime comparison. Comparative studies of lexical semantics belong to relevant and up-to-date issues of contemporary linguistics. Moreover, the research of lexical composition of English, Ukrainian and Hungarian languages is closely connected with the typological model construction of correlation between lexical systems of the languages possessing different structures.

\section{Comparative lexical semantics: new approach to its study}

Lexical semantics is considered to be a complex and multifold object of both comparative and typological analyses which explains the fact that its studies began only in the 60s and 70s, and less has been done in this direction since that time. Among the main reasons for this, the following ones should be mentioned:a) heterogeneity of the language's semantic nature; b) considerable influence of extra-lingual factors; c) system and structural hierarchical organization of lexical units and their meanings in language; d) presence of polytypic interrelations and interconnections between words, lexical semantic groups, lexical semantic fields, etc. A complete comparative analysis of lexical semantic language systems should embrace comparison on all levels of the lexical semantic system (level of words, lexemes, lexical semantic groups, lexical semantic fields), and this analysis should be based on the principle of systematicity ${ }^{1}$. Comparative linguistics studies two or more languages in order to compare their structures and to show whether they are similar or different. Comparative linguistics is used in the study of language types and in comparative historical linguistics. It is also used by some applied linguists for establishing differences between the learner's native language and the target language in the areas of syntax, vocabulary, and sound systems ${ }^{2}$.

\footnotetext{
${ }^{1}$ Кочерган М.П. Основи зіставного мовознавства. Київ: Видавничий центр «Академія», 2006. С. 296-297.

${ }^{2}$ Richards J.C., Platt J., Platt H. Longman Dictionary of Language Teaching and Applied Linguistics. England: Longman Group UK Limited, 1995. P. 68. 
Different languages vary considerably, therefore, in the degree to which they differ from each other. It is not only, however, a matter of degree but one of kind. Indeed, while speaking of languages as differing from each other to varying degree is a common-sensical way of talking, there is, at present, no way of measuring the degree of differences in a rigorous or valid fashion. The most obvious way in which differences between languages show themselves is in the mutual intelligibility of their speakers; but here we must remember that mutual intelligibility was not just a function of the linguistic relation between languages, but also had an important socio-psychological component. The other way in which the degree of differences between languages is apparent is in the degree of difficulty the speaker of one has in learning another. Here also we must admit that it is a matter of subjective judgement. The ease or difficulty of learning something is not simply related to the nature of the task but has components of motivation, intelligence, aptitude, quality of teaching and teaching materials; more importantly it depends upon the expectations the learner has of success. Certain languages may be considered difficult to learn by members of a certain community. By being thought difficult they may become difficult. Believing oneself "no good" at something is the surest condition for failure. As in the case of mutual intelligibility, so in the case of difficulty of learning second languages too there is an important socio-psychological factor ${ }^{3}$.

In the comparative studies of two or more languages, less investigated is the linguistic approach to the research of the language systems in their interrelations and interconnections. Of much significance here is the methodology of such studies. The methodology of contrastive linguistics is to a great extent convergent with that applied to a non-contrastive analysis. There exists mainly a difference in the object of both of these sorts of studies. In the non-contrastive (intralingual) approach we may compare various structures of the same language with each other while the contrastive (interlingual) approach allows us to extend this method of analysis on various structures of two or more different languages being confronted. Thus, theoretically there are no limitations imposed upon the comparisons of structures in any two languages, but from the practical point of view not every comparison has the same value. Contrastive inquiries are not, of course, art for art's sake but should pursue some definite goals. Therefore, it is not astonishing that we face the problem of determining which structures in two or more languages are comparable. A particular language system may be thought of as possessing two statuses, i.e. a) non-contrastive and b) contrastive. The former one is based on the oppositions of its own subsystems. The latter is always relative depending on the languages being compared. Thus, a specific structure of one language

\footnotetext{
${ }^{3}$ Pit Corder S. Introducing Applied Linguistics. London: Penguin Books, 1973. P. 226.
} 
shapes the contrastive status of another language ${ }^{4}$. Any intralingual analysis cannot be regarded as exhaustive, because the larger the number of languages with which a given language is confronted the more complete its description will be and the fuller its typological status. The choice of an appropriate theoretical framework is determined by the practical aims.

There are many different approaches to the way in which meaning in language is studied. Semantic classification of lexis based on its formalized analysis combines pure linguistic and structural mathematical methods. The abovementioned analysis has been successfully applied to etiquette lexis research on the material of English, Ukrainian and Hungarian languages. ${ }^{5}$ It was also applied to comparative lexical semantic research of the nouns denoting success, good and evil, the verbs "to conflict" in English and Ukrainian, happiness in English and Slovak and many other groups of lexis. The application of the analysis in question presupposes the following successive steps: to choose the material of the research, we are to introduce formal, purely language criterion-belonging of the words under analysis to a definite part of speech. Methodology of collecting the language material and analyzing the seme stock of the words' lexical meanings lies in the following procedures:

- from the biggest authoritative explanatory dictionaries of the languages under study the words denoting, in our case etiquette, are copied out;

- on the basis of the obtained lists of words, the card indices are piled;

- both qualitative and quantitative analyses of the words, as well as their semantics are carried out;

- next step is matrix modelling, in which the lists of lexical units are placed vertically and the lists of semes (components of meaning) - horizontally;

- the sign (+) indicates common semes found in the lexical meanings of the words under study. The obtained lists of both lexical units and semes in the matrix are grouped in descending order due to the seme number expression from the most frequently used to rarely occurring ones;

- the matrix serves as a basis for a lexical semantic field modelling in the form of a graph, which makes it possible to pass from the seme and lexical structures as autonomous microsystems' analyses to the study of words' correlations. In this respect the obtained lexical semantic field is treated as an independent system, a structural unity of words (its elements) characterized by close relationships with other fields within the language system.

${ }^{4}$ Banczerowski J. Some Contrastive Considerations about Semantics in the Communication Process // Amsterdam Studies in the Theory and History of Linguistic Science. Series IV. Current Issues in Linguistic Theory. Volume 12. Amsterdam: John Benjamins B.V., 1980. P. 325.

${ }^{5}$ Фабіан М.П. Етикетна лексика в українській, англійській та угорській мовах. Ужгород: Інформаційно-видавниче агентство «IBA», 1998. 256 с. 
Each language material analysis requires its own matrix modelling composed of the list of lexical units placed vertically, and the semes horizontally. It vividly presents semantic characteristics of the words under study. It also discloses all possible specific characteristics of lexical units: their common and distinctive features, place in the language system, types of correlations within the vocabulary of the language, etc. Semantics of the words under study is defined and described with the help of: tables;

- matrix analysis of the words' seme structure for constructing the

- scheme of lexical semantic field on the basis of the already constructed tables;

- both tables and fields' analyses on the basis of their typological comparison due to the mathematical principle of sets' intersection;

- description of words' correlation in the fields, types of their connections and peculiar characteristics.

Matrix method of presenting the semantic relations between the words is treated as a metalanguage for the description of the words under analysis, and the matrix in the form of a table- as a model of the system of semantic relations, on the one hand, and the semantic structure of the lexis under study, on the other. This model fixes the semantic relations between etiquette words in the form of columns and lines of the same length, in which the correlation of the words and their meanings is marked by the sign (+). After matrix modelling of the lexical units in each language separately, their comparative qualitative and quantitative analyses can be carried out. The formalized analysis of lexical semantics' study can be applied to the research of any group of lexis, e.g. nouns, verbs, adjectives denoting feelings, their forms and ways of expression, emotions, attitudes to objective reality, perception of the world, etc. On the basis of the obtained matrices, the graphs of lexical semantic fields can be constructed, in which their elements (words) acquire new possibilities of establishing various types of relationships not only within this field, but with other ones as well. They form macro and microfields, containing their own centres and periphery, join other centres' periphery owing to direct, indirect, two-, three-, four-, etc. component links. From the graph of the lexical semantic field, further change (or not) of words' semantics can be predicted. Moreover, empty spaces both in matrix and the field indicate the potential ability to be filled by some other related or unrelated words denoting various groups of lexis. 


\section{System and structural organization of etiquette nouns in English, Ukrainian and Hungarian}

In today's globalized world, English, Ukrainian and Hungarian do not only coexist, but they also interact, interfere, and open new possibilities for language interchange as well as for the new groups of lexis formation. Changes in vocabulary and meaning are often the most vivid and interesting to study. They show how language changes reflect the objective reality, our attitude to it, our world view, historical developments, new knowledge, new beliefs, experiences, problems, and the like. The word stock of a language, the vocabulary, also changes. It develops primarily in two ways: 1 ) new words constantly come into a language to meet new demands; 2) the words in the language change through use. English, Ukrainian and Hungarian, like other languages, constantly change, they are influenced by current events, by other languages, and by the tendency of people to modify their languages as they use them.

Changes in meaning reveal the ingenuity and the flexibility of the human mind. They are the most fascinating parts of language studies, because they show how people use their languages, how they adapt words for new needs. Changes may reflect the progress of society. Other changes show how people reach for cleverness, freshness, and humour in their use of words. In any culture at any time there are words which are used by sloganisers, political or otherwise, to stand, some from positive and some for negative values, judged as such by that culture. ${ }^{6}$ The rules of language are social and are closely connected with people's life standards, values, upbringing, etc.

Differences in the language usage grow as an expression of various kinds of social and cultural differences. Different usage habits develop as characteristics of an age group, of one sex rather than other, of different social, economic, or occupational groups, or of people with different educations. ${ }^{7}$ Furthermore, languages are aspects of culture common to all human societies. Languages are in a continual state of change, as social conditions change; as contacts between classes, peoples, and races touch and go, as ideas pass and repass. Language has been compared to the shifting surface of the sea; the sparkle of the waves like flashes of light on points of history. For example, the description of respect to oneself is expressed in Ukrainian by etiquette words самоповага і самопошана. Their corresponding meanings in English are selfregard, self-respect and önbecsülés in Hungarian. These cross-language equivalents are characterized by the same external form (camo-, self-, ön-). Comparative analysis of the nouns denoting etiquette revealed the specificity of their semantics: the Ukrainian word самооцінка has the equivalent selfestimate in English and önbecsmérlés in Hungarian. In Ukrainian, the lexical

\footnotetext{
${ }^{6}$ Jackson H. Words and their Meanings. London and New York: Longman, 1991. P. 59.

${ }^{7}$ Gorrell R.M., Brown M.M. Writing and Language. Part I. New York: Harcourt Brace
} Jovanovich, Inc., 1972. P. 278. 
unit under study does not have etiquette connotations, whereas in Hungarian it denotes the understated evaluation of oneself in public (mások elött való kisebbitése), and in English - rather high positive degree of one's evaluation (valuation of oneself).

In modern lexicology as well as in a comparative one, the emphasis is no longer on the consideration of words as isolated lexemes in the vocabulary of the language (languages), to be treated one by one in terms of their forms and meanings. Much rather the emphasis is on the ways in which the vocabulary hangs together as a system or as a system of systems with each lexeme having formal and more especially semantic links with many other lexemes in the vocabulary. Indeed, it is considered impossible to make an adequate and exhaustive description without these links and relationships' study. Comparative research of etiquette semantics in the lexical systems of nonrelated languages presupposes the following successive steps:

1) to determine the groups of words denoting etiquette as integral systems possessing definite structures;

2) to describe the comparable properties and parameters according to the worked out terminological apparatus and methodology of the language material analysis;

3) to carry out the semantic analysis of etiquette words in sociolinguistic, psycholinguistic and cognitive aspects;

4) to present the etiquette lexis as a fragment of the lexical systems of English, Ukrainian and Hungarian which has its definite system and structural organization, occupies its definite place in the semantic space and possesses both common and distinctive features in the languages in question.

Among specific peculiarities of etiquette semantics' comparative study in the lexical systems of English, Ukrainian and Hungarian, one can mention:

a) a motive which determines the choice of three languages of different structures for comparison and is influenced by the external, socio-cultural factors, and is closely connected with the processes of cognition, consciousness, mentality of people;

b) an attempt of language typology to embrace the largest number of world languages and correlate them owing to minimum general and universal structural properties, whereas comparative linguistics does not focus on the big quantity of languages, but tries to correlate them as to maximum number of properties which are characteristic of present day languages; language typology functions within internal linguistics limiting itself to language structures' analysis, whereas comparative linguistics concentrates on environment peculiarities and spheres of usage of languages under comparison, in correlation of conventional norms and non-verbal communication in the communities who use them;

c) an interest to those peculiarities and specific characteristics of etiquette words in the languages under comparison which cannot be noticed without their inner semantics' study, emotional colouring, normative and situational usage. 
Complexity of comparative etiquette lexis research lies in the fact that semantics of English, Ukrainian and Hungarian represents a sphere of multistage relations from language signs to thinking and objective reality, and to etiquette words in their relationships with each other. Moreover, social aspects of semantics still remain less studied in contemporary linguistics and rarely appear as the basis of comparative research. The comparative analysis of the social aspects of etiquette words' lexical meanings in English, Ukrainian and Hungarian language systems makes it possible to: a) obtain information on what components of social reality are marked on the structure of etiquette words' lexical meanings; b) determine the degree of semantics' social components and c) reveal the social motivation of nationally cultural stereotypes. The latter represent the essential stage of the comparative analysis of forms and means of etiquette expression in unrelated languages. The establishment of the system character of etiquette lexis in English, Ukrainian and Hungarian, its relations with other language systems, their interrelations and interactions give possibility not only to describe and all-round analyze the groups of nouns denoting etiquette in each of the languages under study, but also to carry out their comparative analysis to reveal common and distinctive features of their lexical semantics. The comparative study of etiquette words in English, Ukrainian and Hungarian is carried out on the basis of:

- preliminary processing of linguistic facts by means of their uniform description to establish maximum possible commensurability of the languages under analysis;

- singling out the relevant properties for their comparison based on quantitative and qualitative parameters.

Lexical semantic comparative research of the nouns denoting etiquette in English, Ukrainian and Hungarian lies in their matrices comparison according to: 1) degree of etiquette words' polysemy (words placed vertically); 2) etiquette nouns' seme stock character (semes placed horizontally). Because of enormous amount of language material in three unrelated language systems, only a part of it will be analyzed in this paper in detail. On the whole, etiquette lexis is expressed by 135 English $^{8}, 147$ Ukrainian $^{9}$ and 268 Hungarian $^{10}$ lexical units which possess their specific features. All the nouns in the languages under study form separate groups owing to their degree of polysemy. Moreover, owing to their semantics, they are classified into definite groups with the further subdivision into subgroups. The words with the highest degree of polysemy in English denote respect, recognition of the person, his/her place in the society, role in everyday activities, etc. (respect, honour, reference, grace, price, respection, regard, consideration, credit, concern, figure, account and others).

\footnotetext{
${ }^{8}$ The Oxford English Dictionary: In 12 volumes. London: Oxford University Press, 1961.

${ }^{9}$ Словник української мови: В 11-ти томах. Київ: Наукова думка, 1956.

${ }^{10}$ A Magyar Nyelv Értelmezõ Szótára: 7 kötetben. Budapest: Akadémiai Kiadó, 1966.
} 
In Ukrainian, the polysemantic nouns express a respectful attitude towards others, the person's moral values, both positive and negative traits of character (увага, любов, честь, зверхність, зглядь, пошанування, признання, пиха, благоговіння). In the Hungarian language, polysemantic etiquette words describe the mentality, physical state of mind, world view of the person as well as the feelings of honesty, esteem, justice, trust, and the like (ember, respektus, tisztesség, móres, reverencia, becsület, buzgalom, buzgóság, dísz, hit, hitel). To the common features of polysemantic lexical units denoting etiquette in English, Ukrainian and Hungarian belong:

- an indication of respect (зглядь, пошанування, вшанування; respect, respection, regard; respektus, tisztesség),

- human values (честь, слава, велич; credit, concern, pride; becsület, hit, kegyelet),

- peculiarities of etiquette behaviour and communication (yвaza, любов, прийом; grace, courtesy, distinction; üdvözlet, bizalom, szó, név, szív),

- description of negative traits of human character (зверхність, пиха; unworship; semmi, piszok).

On the whole, etiquette semantics of polysemantic nouns in the languages under study is marked by positive connotations and characterizes the notion of etiquette. This generalization gradually turns into specification during the transition of polysemantic words into the ones with middle degree of polysemy, and finally to the monosemantic lexical units. Below are the fragments of matrices composed of etiquette nouns in English, Ukrainian and Hungarian to represent the correlations between words and their meanings.

Lexical units with the middle degree of polysemy in English, Ukrainian and Hungarian occupy middle positions in the matrices as if dividing them in halves. They serve as a transition zone and connect polysemantic nouns with the monosemantic ones. This zone has its specificity in each of the languages under study.

The nouns with the middle degree of polysemy in Ukrainian denote the person (звеличник, цінитель, поклонник, обожнювач, шанувальник, патріарх, прибічник, прихильник, людина, послідовник, важниця, маестро), his/her moral values (пістет, шана, гордість, велич, пристрасть, достоӥнство, ласка, прихильність, авторитет, заслуга, приязнь, уклінність, гідність, самопошана), attitude to the religion (святиня, храм, святилище, святотатство, святість), observance of etiquette norms of behaviour and everyday communication (преклоніння, вшанування, схиляння, поклоніння, вітання, уклін, хліб-сіль).

As opposed to the Ukrainian, the English matrix includes the lexical units denoting in the first place socially determined characteristics of a person (reputation, liking, recognition, estimation, respectiveness, exaltation, fame), his/her features and properties (kindness, tenderness, honesty, goodwill, self- 
regard, appreciation), and also condemnation of actions, deeds, disrespectful attitudes towards other people in the society (shame, indifference, reward, rudeness, disfavour, degradation, dishonour, irreverence, infamy, coarseness, disesteem, disregard).

Fragment of English matrix

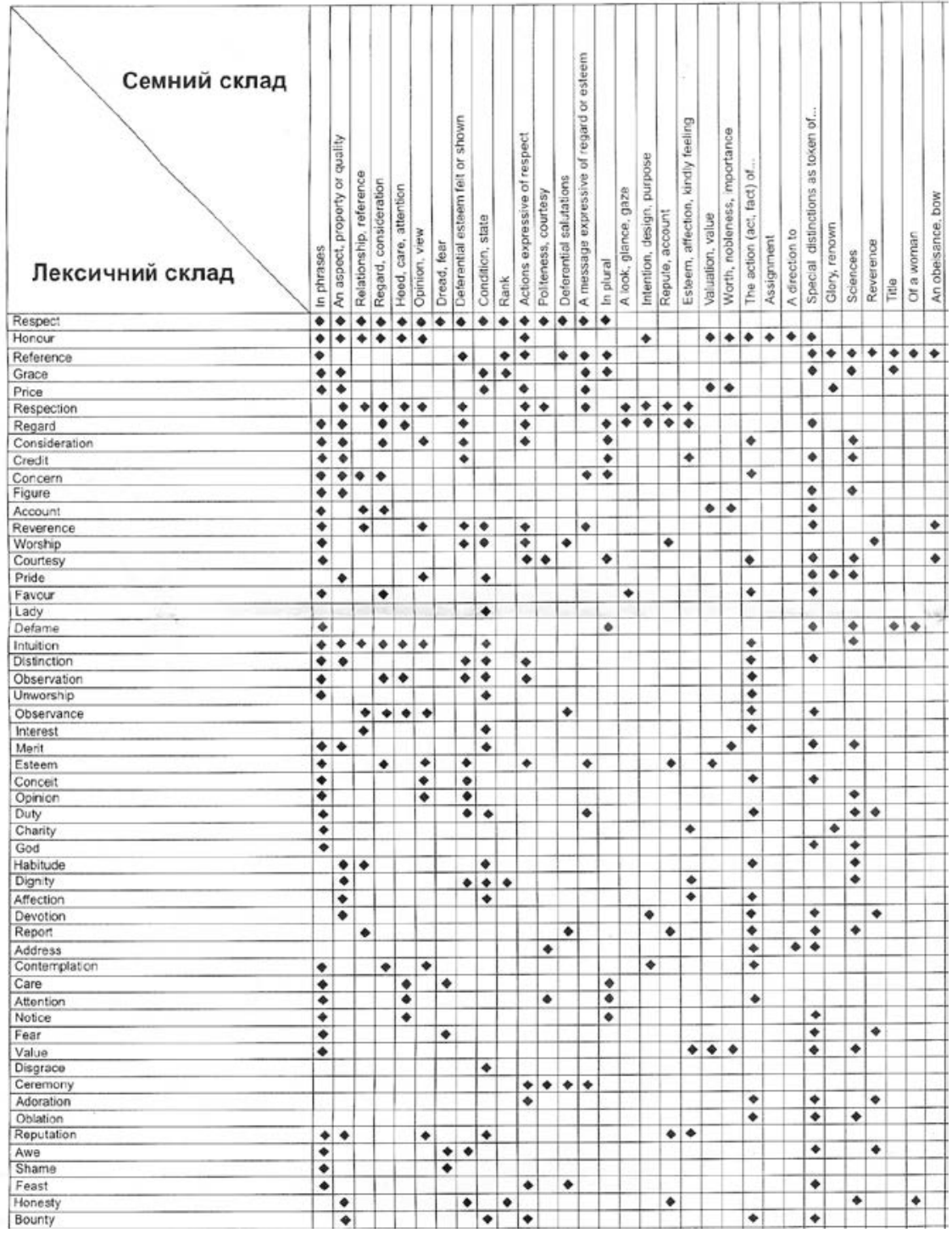


Fragment of Ukrainian matrix

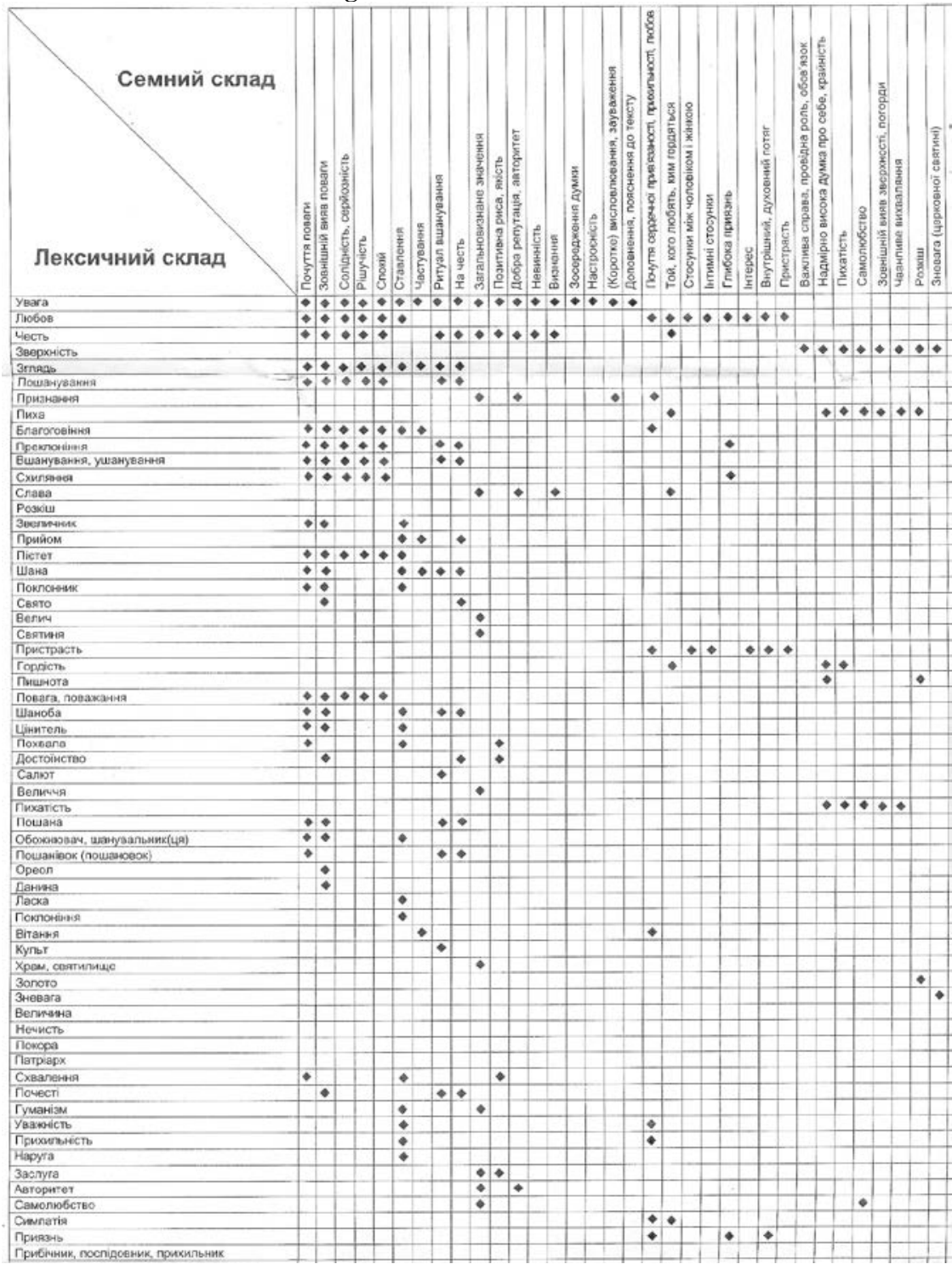

Hungarian etiquette words with middle degree of polysemy in the matrix reveal everyday life and everyday activities of a person which are closely connected with his/her inner world, his/her emotions, world view, highly esteemed features of character, abilities to overcome difficulties, troubles 
(tisztelet, megbecsülés, becsülés, becs, méltánylás, dicsőség, tisztaság, elismerés, nyíltság, tolerancia, becsületérzés), religious ceremonies (vallás, istenség, isten, koszorú, babér, templom, oltár, istentisztelet, szellemidézés) and things of everyday importance (szó, név, cím, szív, vélemény). Hungarian lexical units reveal a variety of forms and ways of etiquette description, for example, in letters, verbal and non-verbal communication, etc. (üdvözlet, fogadás, érdem, ajándék, ünnep, szerencsekívánat, köszönet, hála, üdv, csók, kalap). Matrices vividly represent the boundaries of such transitions which help establish semantic regularities of lexical semantic groups formation as well as disclose the relationships between them. This is possible owing to the correlations between empty and filled matrix cells.

In the process of gradual transition from the nouns with middle degree of polysemy to monosemantic ones, the etiquette lexis discloses its smallest but the most essential properties. The latter play a significant role in the system and structural organization of etiquette lexis in modern English, Ukrainian and Hungarian. If on the level of both polysemantic and words with middle degree of polysemy the distinguishing feature of etiquette lexis is its common to mankind (in Ukrainian), social (in English) and psycho-physiological (in Hungarian) character, then on the level of monosemantic nouns there is a tendency for the convergence of these languages according to their quality indicators.

Despite a quantity divergence (Ukrainian matrix is composed of 36, English - 7, Hungarian - 54 nouns), etiquette semantics displays the universal character of the language to be the means of human communication. For instance, monosemantic etiquette words in Ukrainian matrix, the same as in English and Hungarian, denote the feeling of respect, its expression (почаноба, поважність, шанування, величання, звеличування, довіра, довір'я; estimableness, respectfulness; becslés, tisztességérzés, közbecsülés, köztisztelet, közbiztonság, föhajtás) and the positive traits of a person's character (славетність, привітність, цирість, чесність; серйозність, солідність, рішучість, чемність, гречність; self-estimate; becsületszó, becsületügy, önbecsülés).

Lexical meanings of monosemantic etiquette words possess also a number of distinctive characteristics to name:

1) a person, his/her social position, occupation connected with the person's living conditions and everyday activities. For example, English monosemantic word appreciator denotes one who appreciates or forms an adequate estimate and in this meaning it stands close to the Hungarian becslö, becsár.

In Ukrainian matrix of etiquette lexis, monosemantic words indicate exclusively disrespectful people who possess improper qualities, violate social norms of behaviour, have bad attitude towards others and their negative traits of character (посіпака, святотатець, зневажник, неприятелька, неприхильник, неприхильниця; блюзнірство, зневажливість, неласкавість, нелояльність, нечесність, неприхильність, гордовитість, зарозумілість, нешанобливість). 


\section{Fragment of Hungarian matrix}

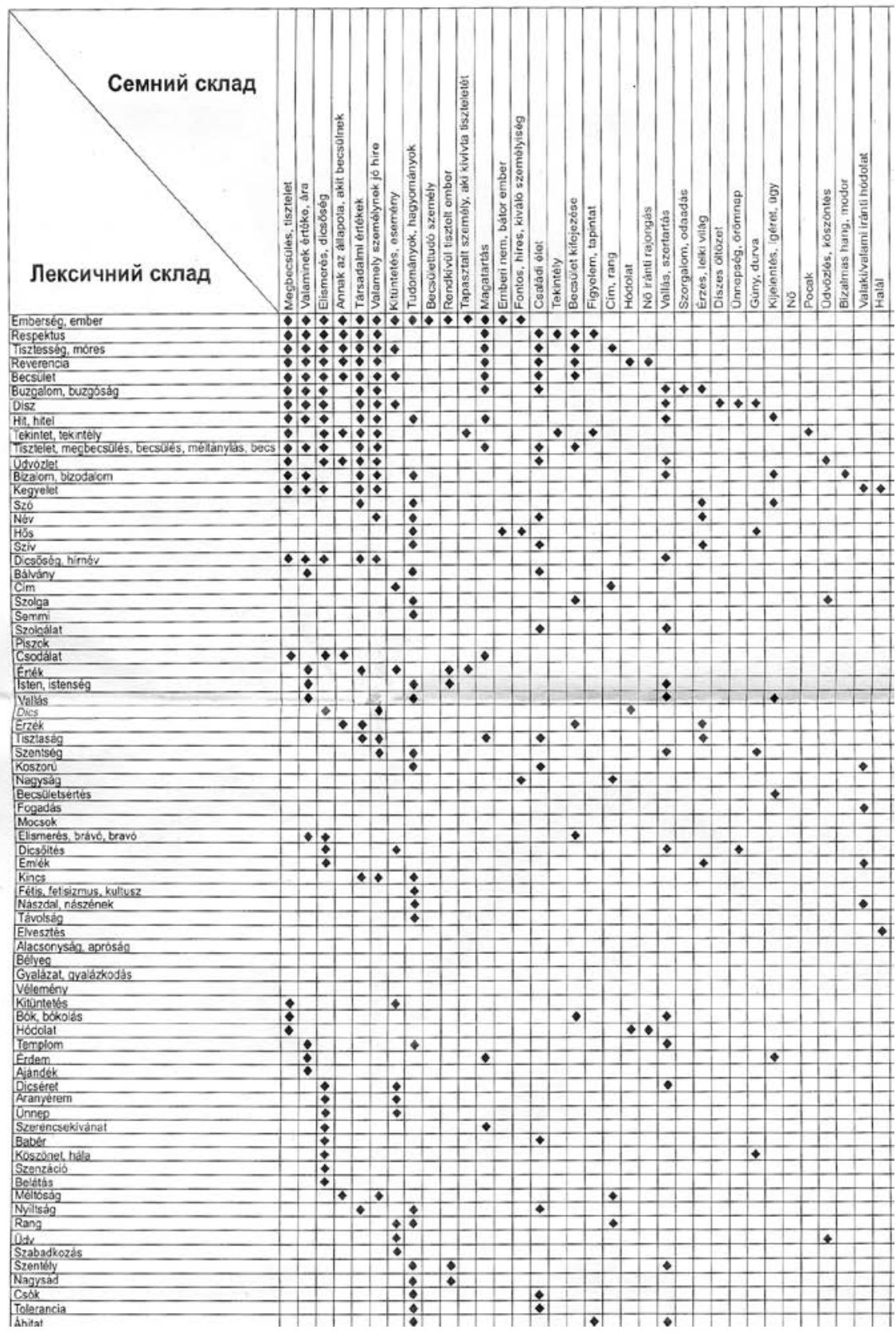


Hungarian matrix of etiquette lexis, as opposed to English and Ukrainian, represents a wide range of personality designation as a/an:

- example of human virtues, the qualities worth imitation (becsülettudó, hódoló, tisztelö, tudó, hazámfia);

- property which distinguishes a person from others because of his/her persistence, merit, recognition in various spheres of human activities, and which lead to promotion, higher social status, rank, honours (díszdoktor, díszszónok, dísztag, díszpolgár, díszelnők, fó-fö);

- characteristics of a person engaged in dishonest labour (huncut, zugügyvéd, becsvágyó).

2) Negative sides of human nature which are observed in Hungarian matrix (nagyravágyás, káromlás, tiszteletlenség, elmefuttatás, semmibevevés, szégyenfolt, zsiványbecsület, rontás), whereas the English matrix contains monosemantic lexical units expressing disrespect, misesteem.

3) The peculiarity of Hungarian monosemantic nouns lies in the fact that they contain a group of etiquette nouns denoting solemn events, red calendar days celebration (díszfelvonulás, dísztribün, díszlóvés, díszülés, szervita), organization of evenings, meetings, dinner parties in honour of somebody (diszhangverseny, tiszteletpéldány, díszelöadás, díszpáholy), and also forms of expressing respect, love, admiration, etc. to a person because of his/her family or personal celebrations, farewell date, etc. (ajándékmǘsor, díszebéd, díszvacsora, búcsúpohár, búcsúvacsora). All the abovementioned linguistic data are discussed in terms of cultural differences as well as similarities, because different people do not only have different languages, they have different world views which are reflected in their languages. In the sense that language reflects culture, this is a very important observation and the existence of different world views should not be ignored when different languages or language varieties are studied. ${ }^{11}$ The correlation between languages and cultures is beyond doubt in modern linguistic paradigm which has a vividly revealed anthropocentric character. ${ }^{12}$ Moreover, words with special culture-specific meanings reflect and pass on not only ways of living characteristic of a given society but also ways of thinking ${ }^{13}$.

To conclude, the presentation of etiquette lexis in English, Ukrainian and Hungarian in the form of matrices gives possibilities not only to reveal both common and distinctive features of its system and structural organization, but also on this basis to carry out the comparative lexical semantic research of the nouns denoting etiquette in three unrelated languages. Comparative analysis of

${ }^{11}$ Yule G. The Study of Language. An Introduction. New York: Cambridge University Press, 1985. P.196.

12 Левицький А.Е., Святюк Ю.В. Етнономінації у дзеркалі міжкультурної комунікації. Київ: Логос, 2011. С.7.

${ }^{13}$ Wierzbicka A. Understanding Cultures Through Their Key Words. English, Russian, Polish, German, and Japanese. New York, Oxford: Oxford University Press, 1997. P. 5. 
the lexical units made it possible to highlight the notion of etiquette as a phenomenon caused by social, national-cultural and individual-psychological factors. In the languages under study it is revealed by both linguistic and extralinguistic factors which influence them and are represented by: a) a word as a means of etiquette expression; b) polysemy as a means of etiquette lexis system organization; c) semantic relations between lexical units - the basis for structuring of polysemantic words' meanings; d) the word's semantic space in the lexical system of the language, where owing to the close relationships between the words, lexical semantic groups and lexical semantic fields are formed with etiquette nouns being their elements.

The use of the described formalized analysis of lexical semantics helps unite analysis and synthesis for the study etiquette lexis: on the one hand, it is researched as a part of each separate language, and, on the other, its comparative analysis has been carried out to reveal its common and distinctive characteristics.

Such a representation of etiquette semantics makes it possible to disclose both lexical semantic and seme structure of the nouns denoting etiquette in English, Ukrainian and Hungarian by:

- the degree of their polysemy;

- the types of connections between them;

- semantic peculiarities of etiquette expression in each of the languages under study;

- the degree of seme functionality;

- qualitative relationships between semes.

The present research of lexical semantic and seme structures of etiquette nouns in English, Ukrainian and Hungarian reveals their quantitative as well as qualitative characteristics which, in their turn, make it possible to determine common and distinctive features of the nouns denoting etiquette.

To the common features of etiquette lexical units in the languages under study belong:

- availability of polysemy, synonymy, antonymy;

- direct and indirect links between etiquette words;

- explicit and implicit representation of etiquette by words in the languages under study;

- semantic reactivity of polysemantic etiquette words;

- division of polysemantic etiquette lexical units into groups according to the degree of polysemy;

- availability of monosemantic words;

- availability of seme stock in which there exist various relations between semes, the same as between etiquette nouns, and it gives all grounds to state that semes also make up systems having their hierarchical structures;

- division of semes into multifunctional and monofunctional; 
- two types of monofunctional semes: the ones which are the components of the lexical meanings of etiquette words, and those which are the parts of monosemantic words' lexical meanings.

To the distinctive features of etiquette lexical units in English, Ukrainian and Hungarian belong:

- quantitatively different both lexical and seme stock of the lexis fragment under study;

- dissimilar character of etiquette lexis: common to mankind (in Ukrainian), social (in English) and psycho-physiological (in Hungarian);

- qualitatively new types of etiquette relationships between people: charity (in English), social and historical (in Hungarian);

- different semantic space filled by etiquette nouns;

- indirect links between etiquette words predominate over direct ones in Hungarian as opposed to English and Ukrainian;

- high degree of etiquette words' combinability with other parts of speech words in English as opposed to Ukrainian and Hungarian;

- presence of national specificity of etiquette description in the languages under study (хліб-сіль; kalap; kézcsók).

Within etiquette lexis in English, Ukrainian and Hungarian, three main emotional types which correspond to three aspects of objective reality have been revealed and described: actions with their consequences, people in their everyday activities and things as well as abstract notions. The abovementioned aspects being interconnected, condition and complement one another.

Comparative research of qualitative and quantitative peculiarities as well as characteristics of etiquette nouns in English, Ukrainian and Hungarian language systems gave possibilities to, for the first time, synchronically represent etiquette lexis in the form of matrices as the fragments of system wellarranged language groups from the point of view of their system and structural organization, interrelationships between the compound elements, the analysis of links between adjacent and non-adjacent lexical semantic groups and to carry out their typological analysis.

\section{CONCLUSIONS}

Comparative lexical semantic study of both related and unrelated language systems belongs to one of the most relevant and topical issues of contemporary linguistics. Being one of the youngest branches of linguistics, comparative language study attempts to find out similarities and differences in both philogenically related and unrelated language systems at all levels of their structure. As a rule, it entails a synchronic approach to the study of languages without reference to their origins. On the level of lexis, comparative analysis is applied to reveal the features of sameness and difference in lexical meanings and semantic structures of correlated words in different languages. Though the 
objective reality exists outside human beings and irrespective of the language they speak, every language classifies this reality in its own way by means of vocabulary units. Etiquette words belong to the units of patterned behaviour which have form, meaning, and distribution. Semantics of the nouns under study is culturally determined, because they represent an analysis of the universe as grasped in different cultures. In the comparative studies of two or more languages, less investigated is the linguistic approach to the research of the language systems in their interrelations and interconnections. Of much significance is the methodology of such studies which in the present research lies in a combination of pure linguistic methods with the structural and mathematical ones.

The formalized analysis of the semantic classification of lexis is applied to the comparative study of the nouns denoting etiquette in modern English, Ukrainian and Hungarian to find out similarities as well as differences between them. As a result, on the basis of the obtained language material, the matrices are constructed which reveal the correlations between the lexical units and their meanings in each of the languages under study. Furthermore, etiquette lexis in unrelated language systems is divided into groups of words owing to the degree of polysemy. In their turn, the components of meanings (semes) also form their subsets according to the degree of functionality. Matrices which represent the etiquette lexis as fragments of the lexical systems of English, Ukrainian and Hungarian reveal the place the nouns they occupy in the semantic space of each language, their role, functioning, degree of relationships between them, their potential abilities to establish various types of connections with other ones within the group, direct and indirect links existing between both words and their meanings, and matrices also make it possible to find out both common and distinctive features of the nouns' semantics in the languages under study. Etiquette language research in English, Ukrainian and Hungarian goes hand in hand with corresponding culture studies, and their close interrelations and interdependence help better understand inner mechanisms of the languages' functioning, their system and structural organizations as well as national specificity of the language bearers.

\section{SUMMARY}

The present paper deals with comparative lexical semantic analysis of the nouns denoting etiquette in modern English, Ukrainian and Hungarian languages. The research has been carried out on the material collected from the most authoritative explanatory dictionaries of the languages under study, then analyzed and classified on the basis of new approach to the study of lexical semantics which combines linguistic methods with structural and mathematical ones. The use of this methodology opens new possibilities for treating both related and unrelated languages as systems possessing definite structures composed of hierarchically placed elements. The latter are characterized by 
different kinds of relations within the groups of etiquette nouns, and links of various types with other lexical units outside the mentioned ones. The representation of etiquette lexis in English, Ukrainian and Hungarian in the form of matrices, helps in a formalized way carry out an all-round complex comparative research of etiquette nouns as fragments of the languages' lexical systems to find out their both common and distinctive features. Matrices, in their turn, vividly disclose correlations of different qualitative and quantitative value between lexical units and their meaning components. As a result, the whole lexical stock is divided into groups according to the degree of the words' polysemy. The seme stock is composed of sets depending upon the degree of their functionality. At the same time, much attention is paid to the study of interrelationships between language systems and their corresponding cultures.

\section{REFERENCES}

1. Banczerowski J. Some Contrastive Considerations about Semantics in the Communication Process//Amsterdam Studies in the Theory and History of Linguistic Science. Series IV. Current Issues in Linguistic Theory. Volume 12. Amsterdam: John Benjamins B.V., 1980. 430 p.

2. Gorrell R.M., Brown M.M. Writing and Language. Part I. New York: Harcourt Brace Jovanovich, Inc., 1972. 290 p.

3. Jackson H. Words and their Meanings. London and New York: Longman, 1991. 279 p.

4. Pit Corder S. Introducing Applied Linguistics. London: Penguin Books, 1973. 392 p.

5. Richards J.C., Platt J., Platt H. Longman Dictionary of Language Teaching and Applied Linguistics. England: Longman Group UK Limited, 1995.

6. Wierzbicka A. Understanding Cultures Through Their Key Words. English, Russian, Polish, German, and Japanese. New York, Oxford: Oxford University Press, 1997. 328 p.

7. Yule G. The Study of Language. An Introduction. New York: Cambridge University Press, 1985. 220 p.

8. Кочерган М.П. Основи зіставного мовознавства. Київ: Видавничий центр «Академія», 2006. 424 с.

9.Левицький А.Е., Святюк Ю.В. Етнономінації у дзеркалі міжкультурної комунікації. Київ: Логос, 2011. 192 с.

10.Фабіан М.П. Етикетна лексика в українській, англійській та угорській мовах. Ужгород: Інформаційно-видавниче агентство «ІВА», 1998. $256 \mathrm{c}$. 


\section{LEXICOGRAPHICAL SOURCES}

11. The Oxford English Dictionary: In 12 volumes. London: Oxford University Press, 1961.

12. Словник української мови: В 11-ти томах. Київ: Наукова думка, 1956.

13. A Magyar Nyelv Értelmezõ Szótára: 7 kötetben. Budapest: Akadémiai Kiadó, 1966.

\section{Information about the author:}

Fabian M. P.,

Doctor of Philological Sciences in General Linguistics, Professor, Professor at English Philology Department Uzhhorod National University 14, office 521, Universytetska str., 88000, Uzhhorod, Zakarpattia region, Ukraine 